\title{
The ovarian expression of mRNAs for aromatase, IGF-I receptor, IGF-binding protein-2, -4 and -5 , leptin and leptin receptor in cycling ewes after three days of leptin infusion
}

\author{
M Muñoz-Gutiérrez ${ }^{1,5}$, P A Findlay ${ }^{2}$, C L Adam², G Wax ${ }^{1}$, B K Campbell ${ }^{3}$, N R Kendall ${ }^{3}$, \\ M Khalid ${ }^{1}, M$ Forsberg ${ }^{4}$ and R J Scaramuzzi ${ }^{1}$ \\ ${ }^{1}$ Department of Veterinary Basic Sciences, Royal Veterinary College, Royal College Street, London, UK, ${ }^{2}$ Division \\ of Energy Balance and Obesity, Rowett Research Institute, Bucksburn, Aberdeen, UK, ${ }^{3}$ Department of Obstetrics \\ and Gynaecology, Queen's Medical Centre, University of Nottingham, Nottingham, UK, ${ }^{4}$ Department of Clinical \\ Chemistry, Centre of Reproductive Biology, Swedish University of Agricultural Sciences (SLU), Uppsala, Sweden, \\ ${ }^{5}$ Departamento de Biología de la Reproducción, Universidad Autónoma Metropolitana Iztapalapa, Mexico City, \\ Mexico and ${ }^{6}$ Department of Veterinary Basic Sciences, Royal Veterinary College, Hawkshead Lane, North \\ Mymms, Hatfield, Hertfordshire, AL9 7TA, UK
}

Correspondence should be addressed to RJ Scaramuzzi; Email: rscara@rvc.ac.uk

\begin{abstract}
An experiment was carried out to determine the pattern of follicular expression of mRNAs for aromatase, IGF-I receptor (IGF-IR), IGF-binding protein (IGFBP)-2, -4 and -5, leptin and the long form of the leptin receptor (Ob-Rb) in ten ewes infused with human recombinant leptin $(n=5 ; 1 \mu \mathrm{g} / \mathrm{h})$ or saline $(n=5)$ for $72 \mathrm{~h}$ in the luteal phase of the oestrous cycle. At the end of infusion a follicular phase was induced with a luteolytic dose of a prostaglandin F2 $\alpha$ analogue and the ovaries were collected $32 \mathrm{~h}$ later. One ovary from each ewe was serially sectioned at $10 \mu \mathrm{m}$ using a cryostat at $-20^{\circ} \mathrm{C}$. All follicles $>1 \mathrm{~mm}$ in diameter were counted and probed with specific oligoprobes for aromatase, IGF-IR and IGFBP-2, -4 and -5 and specific riboprobes for leptin and Ob-Rb. Leptin mRNA was detected in theca and granulosa cells and Ob-Rb mRNA was detected only in granulosa cells, of some, but not all antral follicles. Leptin doubled the number of follicles with a diameter $\geq 3.5 \mathrm{~mm}$ $(1.0 \pm 0.36$ (s.E.M.) vs $2.4 \pm 0.24$; control vs leptin; $P<0.02$ ) but had no effect on the number of $\geq 1<3.5 \mathrm{~mm}$ follicles. Leptin had no effect on the number of follicles expressing aromatase mRNA but it decreased significantly the number of follicles expressing mRNA for IGF-IR $(10.7 \pm 0.79$ vs $7.4 \pm 0.81$; control vs leptin; $P<0.05)$, IGFBP-2 $(10.0 \pm 0.82$ vs $5.2 \pm 0.87$; control vs leptin; $P<0.05)$ and IGFBP-5 (5.2 \pm 1.60 vs $1.2 \pm 0.30$; control vs leptin; $P<0.05)$. Leptin increased the diameter of IGFBP-2 mRNA-positive follicles $(1.5 \pm 0.15$ vs $2.2 \pm 0.31 \mathrm{~mm}$; control vs leptin; $P<0.05)$ and increased follicular mRNA expression for IGFBP-2 $(0.30 \pm 0.021$ vs $0.39 \pm 0.027$ arbitrary units; control vs leptin; $P<0.05)$ and IGFBP-5 $(0.46 \pm 0.019$ vs $0.25 \pm 0.053$ arbitary units; control vs leptin; $P<0.05)$. The mRNA for IGFBP-4 was detected in the theca of only two follicles from the control group. Leptin increased the number of follicles expressing Ob-Rb mRNA $(0.25 \pm 0.25$ vs $1.40 \pm 1.17$; control vs leptin; $P<0.05)$ but had no effect on the number expressing leptin mRNA. Leptin decreased plasma concentrations of oestradiol $(P<0.05)$ and increased concentrations of FSH $(P<0.001)$ and insulin $(P<0.001)$, with no effect on glucose concentrations. These data show that: (i) ovine granulosa cells express mRNA for Ob-Rb and leptin and (ii) leptin increased the number of follicles $\geq 3.5 \mathrm{~mm}$. Furthermore, the data suggest that suppression of oestradiol production by leptin is not mediated by inhibition of aromatase gene expression. Finally, the data indicate that the action of leptin in ovarian follicles is mediated by the IGF system, because leptin increased mRNA expression of IGFBP-2 and -5. Leptin also decreased the number of follicles expressing IGF-IR and IGFBP-2 and -5. We suggest that these actions of leptin on the IGF system decrease the bioavailability of IGF-I, resulting in decreased oestradiol production.

Reproduction (2005) 130 869-881
\end{abstract}

\section{Introduction}

The nutritional regulation of folliculogenesis involves, among other factors, the direct action of nutrients and nutritional signals on the follicle (Spicer 2001). In recent years there has been a concerted effort to identify these nutrients and signals and to elucidate their mechanisms of action on the follicle (Clarke \& Henry 1999, Spicer 2001). 
One such putative signal is the adipocyte hormone, leptin, and since its discovery in 1994 (Zhang et al. 1994) there has been a continued interest in establishing the precise role of the leptin system as a mediator of nutritional influences on the follicle (Brannian et al. 1999, Spicer 2001). The intrafollicular insulin-like growth factor (IGF) system is a second candidate system that probably mediates nutritional effects on the follicle and there has been similar interest in establishing its role (Monget et al. 1993, 2002).

The presence of either leptin or its receptor $(\mathrm{Ob}-\mathrm{Rb})$ in the ovary has proven surprisingly difficult to demonstrate and no reports have been published showing their presence in sheep ovarian tissues. However, the presence of mRNA for Ob-Rb, detected using RT-PCR, has been reported for human granulosa lutein cells (Cioffi et al. 1997, Karlsson et al. 1997, Löffler et al. 2001) and for porcine (Ruiz-Cortés et al. 2000) and rodent (Zamorano et al. 1997) granulosa cells. Leptin has been detected in human granulosa cells of pre-antral follicles and in theca from healthy and atretic antral follicles (Löffler et al. 2001).

The intrafollicular effects of leptin may be direct but there are probably interactions with both the insulinglucose system and the IGF system (Zachow \& Magoffin 1997, Zachow et al. 1999, Muñoz-Gutiérrez et al. 2002, 2004). Leptin inhibits IGF-I-stimulated oestradiol secretion from cultured granulosa cells (Spicer \& Francisco 1997, Zachow \& Magoffin 1997, Zachow et al. 1999) and human granulosa lutein cells (Agarwal et al. 1999, Greisen et al. 2000, Ghizzoni et al. 2001, Tsai et al. 2002). These findings suggest that leptin has a negative interaction with the intrafollicular IGF system. We have in vivo confirmation of these observations in sheep with an ovarian autotransplant (Kendall et al. 2004). These data clearly suggest a direct in vivo role for leptin in ovarian steroidogenesis.

In this context, changes in peripheral concentrations of insulin, IGF-I and leptin have been associated with the initiation of follicle waves in cattle and it has been suggested that follicular oestradiol regulates the secretion of these metabolic hormones (Armstrong et al. 2003). Furthermore, leptin expression in adipose tissue is correlated with hepatic IGF-I expression (Houseknecht et al. 2000) and hepatic IGF-I is a major factor controlling both the acute secretion of leptin (Marie et al. 2001, Kadokawa et al. 2003) and follicular function (Monget et al. 1993, 2002, Wang \& Chard 1999).

In this paper we report the results of an experiment to determine the effect of a physiological dose of exogenous leptin, infused at that stage of the oestrous cycle when other nutritional treatments are known to stimulate folliculogenesis and ovulation rate (Smith \& Stewart 1990, Scaramuzzi et al. 1993, Viñoles 2003), on the circulating concentration of oestradiol and on the localization and pattern of mRNA expression for aromatase and components of the IGF and leptin systems in sheep ovarian follicles.

\section{Materials and Methods}

\section{Experimental animals and leptin infusion}

All animal procedures were conducted in accordance with the requirements of the UK Home Office and in compliance with the Animal (Scientific Procedures) Act, 1986.

Ten mature adult Welsh Mountain ewes were used during the natural breeding season. Their oestrous cycles were synchronized using progestagen sponges (Chronogest; Intervet Ltd, Milton Keynes, Northamptonshire, UK) for 12 days. On day 11 of the synchronized cycle the ewes were randomly allocated to two treatment groups: (i) with a freely available maintenance diet of oaten straw and infused i.v. with saline (controls; $n=5$ ), and (ii) with a freely available maintenance diet of oaten straw and infused i.v. with human recombinant leptin (leptininfused; $1 \mu \mathrm{g} / \mathrm{h} ; n=5$ ). The infusions were started on day 12 and lasted $72 \mathrm{~h}$, ending on day 15 of the oestrous cycle, at which time a single i.m. injection of $125 \mu \mathrm{g}$ of the prostaglandin $F 2 \alpha$ analogue (PG), cloprostenol (Estrumate; Intervet) was given to induce luteolysis.

\section{Blood sampling and hormone analyses}

On day 11 of the synchronized oestrous cycle, bilateral venous jugular cannulae were inserted under xylocaineinduced local anaesthesia (Williams et al. 2001). One catheter was used exclusively for infusions and the other exclusively for blood sampling. A $5 \mathrm{ml}$ blood sample was drawn from the sampling catheter every $8 \mathrm{~h}$ starting $8 \mathrm{~h}$ $(1600 \mathrm{~h})$ before the commencement of the infusions (midnight) and continuing until the ewes were killed $104 \mathrm{~h}$ after the start of treatment. The syringe of blood was emptied into a heparinized tube $(20 \mathrm{l} \mathrm{U} / \mathrm{ml})$. The blood was then centrifuged for $15 \mathrm{~min}$ at $1000 \mathrm{~g}$ at $4{ }^{\circ} \mathrm{C}$ and the plasma removed and stored at $-20^{\circ} \mathrm{C}$.

The plasma concentrations of oestradiol $17-\beta$ were determined in every third sample (i.e. daily intervals) until PG injection and then every $8 \mathrm{~h}$ to the end of the experiment. Oestradiol was assayed using a commercial human RIA kit (KE2D; Diagnostic Product Co., Los Angeles, CA, USA) adapted for sheep (Meikle et al. 1997, Viñoles 2003). The detection limit of the assay was $4 \mathrm{pmol} / \mathrm{l}$; the intra-assay and interassay coefficients of variation were 8 and $14 \%$ respectively.

The plasma concentration of glucose was measured every $8 \mathrm{~h}$ using the 'infinity' hexokinase reagent (Sigma UK Ltd, Poole, Dorset, UK) in 96-well plates (Nunclone plates; Nunc (Europe) Ltd, Hereford, UK) and at read $340 \mathrm{~nm}$ on a Benchmark plate reader. The lowest standard used was $25 \mathrm{mg} / \mathrm{dl}$ and all samples in the experiment had plasma concentrations that were above this lower limit. The intra-plate coefficient of variation was $4.5 \%$ and the interassay coefficient of variation was $6.6 \%$.

The plasma concentrations of insulin were measured by RIA (Williams et al. 2001). The detection limit of the assay was $50 \mathrm{pg} / \mathrm{ml}$; intra-assay and interassay coefficients of 
variation were 10.0 and $12.5 \%$ respectively. The plasma concentrations of follicle-stimulating hormone $(\mathrm{FSH})$ were measured by RIA (Campbell et al. 1994, Souza et al. 1997). The detection limit of the assay was $0.1 \mathrm{ng} / \mathrm{ml}$; the intra-assay and interassay coefficients of variation were 7 and $12 \%$ respectively.

\section{Collection of ovaries}

Thirty-two hours after the end of the infusions and PG injections (i.e. during the mid-follicular phase of the oestrous cycle) the ewes were killed with a captive bolt pistol. The ovaries were removed within 5 min of death and examined visually. The ovary with the presence of at least one large, presumably dominant follicle was then frozen rapidly in liquid nitrogen vapour and stored at $-80^{\circ} \mathrm{C}$. The remaining ovary was placed in sterile medium and all follicles $>1 \mathrm{~mm}$ in diameter were dissected free, counted and used to provide granulosa cells for culture experiments that are not reported in this paper.

\section{Follicle counts}

The whole frozen ovaries were serially sectioned at $10 \mu \mathrm{m}$ using a cryostat at $-20^{\circ} \mathrm{C}$. The sections were mounted onto electrostatically charged glass slides (Superfrost plus $75 \times 25 \times 1.0 \mathrm{~mm}$; BDH Benchmark Plate Reader, Biorad Laboratories (UK) Ltd, Hemel Hempstead, Hertfordshire, UK), fixed with neutral buffered formalin (BDH Gurr), washed six times (four times with $1 \times$ PBS, once with $70 \%$ ethanol and once with 95\% ethanol) and then stored in $95 \%$ ethanol at $4{ }^{\circ} \mathrm{C}$. Each ovary produced between 500 and 680 sections and the sections were mounted, four per slide. Every 20th slide was stained with Harris's haematoxylin and eosin and all antral follicles were counted and their maximum diameter estimated from the mean of two measurements of the follicle taken at right angles to each other. The number of follicles from the sectioned ovary was then added to the number of follicles from the dissected ovary to provide an estimate of total follicle population for each ewe. The follicles were classified into two arbitrary classes based on their size; $\geq 1<3.5 \mathrm{~mm}$ and $\geq 3.5 \mathrm{~mm}$. Follicles $<1 \mathrm{~mm}$ in diameter were not included.

\section{Oligoprobes for cytochrome $\boldsymbol{P}_{450}$ aromatase, IGF-I receptor (IGF-IR) and IGF-binding protein (IGFBP) $-2,-4$ and -5}

Established in situ hybridization procedures were used to measure the mRNA expression for cytochrome $P_{450}$ aromatase (Muñoz-Gutiérrez et al. 2002, 2004), IGF-IR, IGFBP-2, -4 and -5 (Perks et al. 1995, Perks \& Wathes 1996, Muñoz-Gutiérrez et al. 2004) on dehydrated and fixed sections. Sequences of every 20th slide were probed with labelled ([ $\alpha-{ }^{35}$ S $]$ dATP, SJ 1334; Amersham Pharmacia Biotech, Amersham, Bucks, UK) specific oligoprobes (sense; 45 mer synthetic oligonucleotides; Table 1). There were four sections on each slide; two were used for the sense probe and two for the antisense probe. The sections were impregnated with labelled probe diluted to a concentration of 100000 c.p.m./ml in hybridization buffer by spreading $100 \mu \mathrm{l}$ over the sections using a small piece of Parafilm. First, $100 \mu \mathrm{l}$ of 'labelled' sense probe was spread over two sections and then $100 \mu \mathrm{l}$ of 'labelled' antisense probe was spread over the other two sections. The slides were then incubated overnight in a humidified box at $42^{\circ} \mathrm{C}$ for aromatase and $50{ }^{\circ} \mathrm{C}$ for the other oligoprobes. After incubation, the sections were washed at room temperature with citrate buffer in a shaking bath for $30 \mathrm{~min}$ followed by $1 \mathrm{~h}$ at $60^{\circ} \mathrm{C}$. The sections were then dehydrated in a gradient of ethanol, air dried and exposed to Biomax MR-1 film for 21 days (Kodak Biomax MR-1; Kodak, Hemel Hempstead, Hertfordshire, UK).

Photographic development and image analysis were carried out as reported (Muñoz-Gutiérrez et al. 2002, 2004). Briefly, the autoradiographic images of the ovarian sections were quantified for labelling using an image analysis system (Seescan plc, Cambridge, UK) to measure the absorbance in the theca and granulosa cell layers. The slides were then emulsion-coated, developed and counterstained with haematoxylin and eosin to confirm the cellular localization of the radiographic signal. The results from the autoradiographs were expressed as arbitrary units of absorbance with linear range of $0.01-2.10$. The nonspecific counts (estimated from the sense probe) were subtracted from the total counts (estimated from the

Table 1 Nucleotide sequences for the sense oligoprobes for aromatase, IGF-IR and IGFBP-2, -4 and -5.

\begin{tabular}{|c|c|c|c|}
\hline Probe & Sense sequence & Reference & $\begin{array}{l}\text { Homology } \\
\text { with sheep [\%] }\end{array}$ \\
\hline $\begin{array}{l}\mathrm{P}_{450} \\
\text { aromatase }\end{array}$ & $\begin{array}{l}376-420 \text { of bovine aromatase gene } \\
5^{\prime} \text {-TGCGCAAAGCCTTAGAGGATGATGTCATCGATGGCTACCCGGTGA-3' }\end{array}$ & $\begin{array}{l}\text { Genbank Z69249, } \\
\text { Furbass et al. (1997) }\end{array}$ & 97 \\
\hline IGF-IR & $\begin{array}{l}352-396 \text { of human IGF-IR gene } \\
\text { 5'-CTCACGGTCATCCGCGGCTGGAAACTCTTCTACAACTACGCCCTG-3' }\end{array}$ & $\begin{array}{l}\text { Genbank NM000875, } \\
\text { Stoeltzing et al. (2003) }\end{array}$ & - \\
\hline IGFBP-2 & $\begin{array}{l}452-496 \text { of ovine IGFBP-2 gene } \\
\text { 5'-GCGCCAGCCCCGAGCAGGTTGCAGACAATGGCGAGGAGCACTCTG-3' }\end{array}$ & $\begin{array}{l}\text { Genbank S44612, } \\
\text { Delhanty \& Han (1992) }\end{array}$ & 100 \\
\hline IGFBP-4 & $\begin{array}{l}\text { 118-162 of ovine IGFBP-4 gene } \\
\text { 5'-CTGGGCAGGGGAATGCGCTGTGGGGTGTACACCCCCGACTGCGGC-3' }\end{array}$ & $\begin{array}{l}\text { Gebnak S77394, } \\
\text { Carr et al. (1994) }\end{array}$ & 93 \\
\hline IGFBP-5 & $\begin{array}{l}291-335 \text { of bovine IGFBP-5 gene } \\
\text { 5'-CTACTCGCCCAAGATCTTCCGGCCCAAGCACACCCGCATCTCCGA-3' }\end{array}$ & $\begin{array}{l}\text { Genbank S52657, } \\
\text { Moser et al. (1992) }\end{array}$ & 100 \\
\hline
\end{tabular}


anti-sense probe) to produce a mean value for the specific hybridization in each follicle.

\section{Riboprobes for leptin and $\mathrm{Ob}-\mathrm{Rb}$}

A 308 bp cDNA was generated by RT-PCR from placental RNA using primers to the partial ovine sequence (Dyer et al. 1997, Genbank accession number U62124) 5'-GATGAGATGGTGCCAACAACTA-3' (120-141) and 5'-TGGGTTTCTATTTCCCATGATC-3' (427-406) (Mercer et al. 1998, Williams et al. 1999). The PCR product was cloned directly into pGEM-T (Promega, Southampton, UK). A 501 bp cDNA, was isolated by RT-PCR from ovine adipose tissue RNA using the following primers to the ovine leptin sequence (Simmons et al. 1997, Genbank accession number U84247) 5'-ATGCGCTGTGGACCCCTGT-3' (1-19) and 5'-GCACCCGGGACTGAGGTCC-3' (501-483). The RT-PCR product was cloned directly into pGEM-T (Promega). Plasmids were linearized using Ncoi or Sacl and transcribed with T7 or SP6 RNA polymerase respectively, to generate sense and antisense riboprobes for in situ hybridization.

Established in situ hybridization procedures (Mercer et al. 1998, Williams et al. 1999, Archer et al. 2002) were used with minor modifications. Briefly, slides were fixed in $4 \%$ paraformaldehyde, acetylated and hybridized overnight at $58{ }^{\circ} \mathrm{C}$ using ${ }^{35} \mathrm{~S}$-labelled riboprobes at a concentration of $1-1.5 \times 10^{7}$ c.p.m./ml. Slides were then treated with RNase $A$, desalted with a final high stringency wash (30 min), in $0.5 \times$ saline-sodium citrate at $60^{\circ} \mathrm{C}$, dried and exposed on Hyperfilm $\beta$-max film (Amersham Pharmacia) for 21 days. Frozen hypothalamic (Ob-Rb) and placental (leptin) tissues sectioned at $10 \mu \mathrm{m}$ were used as positive controls and sequences of every 20th slide from the serially sectioned ovaries were probed for $\mathrm{Ob}-\mathrm{Rb}$ and leptin. Photographic development and image analysis were carried out as described above for the oligoprobes.

\section{Statistical analyses}

The effect of treatment on the plasma concentrations of glucose, insulin and oestradiol were analysed using a split-plot ANOVA and the effect of time was then compared by further post-hoc testing using Tukey's method (SAS 1995). The effect of treatment on the (i) number of follicles, (ii) relative concentration of mRNA, and (iii) follicle diameter was analysed using one-way ANOVA. Fisher's exact test was used to test effects of treatment on the proportion of follicles expressing mRNA for each probe. The effects of treatment on patterns of mRNA co-expression were analysed as proportions, also using Fisher's exact test.

\section{Results}

Daily monitoring of plasma progesterone concentrations was used to confirm the physiological status of the ewes. These data show that one control ewe had a persistent corpus luteum. This animal has been excluded.

\section{Number and distribution of follicles}

There was no treatment effect on the number of follicles in the $\geq 1<3.5 \mathrm{~mm}$ size class (Table 2 ). However, there was a significant effect of treatment on the number of follicles in the $\geq 3.5 \mathrm{~mm}$ diameter size class; leptin infusion increased the number of follicles $\geq 3.5 \mathrm{~mm}$ approximately 2-fold ( $P<0.02$; Table 2).

\section{Ovarian $P_{450}$ aromatase}

Aromatase mRNA expression was assessed in 93 follicles $>1 \mathrm{~mm}$ in diameter and expression was detected in the membrana granulosa of ten $(10.8 \%)$ follicles from eight ovaries. In seven of these, the aromatase-positive follicle was also the largest follicle present. The average number of aromatase-positive follicles was not affected by leptin infusion (Table 3), neither was the maximum diameter (Table 3) nor the concentration of aromatase mRNA (Table 3).

\section{The ovarian IGF system}

The known presence (Reynolds et al. 1997, Gadd et al. 2000) of mRNAs for: IGF-IR, in endometrial glands and caruncular stroma; IGFBP-2, in placentome capsule; IGFBP-4, in endometrial glands, placentome capsule and caruncular stroma; and IGFBP-5, in luminal epithelium, placentome capsule, caruncular stroma and

Table 2 Mean \pm S.E.M. number of follicles in two size classes and the proportion of follicles with mRNA expression for aromatase, IGF-IR, IGFBP-2 IGFBP-5, the signalling form of the leptin receptor (Ob-Rb) leptin in follicular phase ovaries from Welsh Mountain ewes infused with saline (control) or $1 \mu \mathrm{g} / \mathrm{h}$ human recombinant leptin (leptin) for $72 \mathrm{~h}$ in the late luteal phase of the oestrous cycle.

\begin{tabular}{|c|c|c|c|c|c|c|c|c|c|}
\hline \multirow[b]{2}{*}{ Treatment } & \multirow[b]{2}{*}{ Follicle diameter (mm) } & \multirow[b]{2}{*}{ Mean number of follicles } & \multicolumn{7}{|c|}{ Probe } \\
\hline & & & Aromatase & IGF-IR & IGFBP-2 & IGFBP-4 & IGFBP-5 & $\mathrm{Ob}-\mathrm{Rb}^{1}$ & Leptin $^{1}$ \\
\hline Control $(n=4)$ & $\geq 3.5$ & $1.0 \pm 0.36^{\mathrm{a}}$ & $3 / 4^{\mathrm{a}}$ & $4 / 4^{\mathrm{a}}$ & $1 / 4^{\mathrm{a}}$ & $0 / 4^{\mathrm{a}}$ & $0 / 4^{\mathrm{a}}$ & $0 / 4^{\mathrm{a}}$ & $2 / 3^{a}$ \\
\hline Leptin $(n=5)$ & & $2.4 \pm 0.24^{b}$ & $5 / 8^{\mathrm{a}}$ & $7 / 8^{\mathrm{a}}$ & $7 / 8^{b}$ & $0 / 8^{a}$ & $1 / 8^{\mathrm{a}}$ & $2 / 7^{\mathrm{a}}$ & $2 / 3^{a}$ \\
\hline Control $(n=4)$ & $\geq 1<3.5$ & $23.2 \pm 2.70^{\mathrm{a}}$ & $2 / 43^{\mathrm{a}}$ & $30 / 43^{a}$ & $25 / 43^{a}$ & $2 / 43^{a}$ & $13 / 43^{\mathrm{a}}$ & $1 / 38^{\mathrm{a}}$ & $2 / 7^{\mathrm{a}}$ \\
\hline Leptin $(n=5)$ & & $24.2 \pm 2.88^{\mathrm{a}}$ & $0 / 38^{a}$ & $22 / 38^{b}$ & $14 / 38^{b}$ & $0 / 38^{b}$ & $4 / 38^{b}$ & $5 / 36^{\mathrm{a}}$ & $5 / 13^{\mathrm{a}}$ \\
\hline
\end{tabular}

Values with different superscripts between treatments within columns differ significantly $(P<0.05)$.

${ }^{1}$ Not all follicles were assessed with both these probes. 
Table 3 Mean \pm S.E.M number, maximum diameter and concentration of mRNA for aromatase, IGF-IR and IGFBP-2, -4 and -5 , long signalling form of the leptin receptor (Ob-Rb) and leptin in follicular phase ovaries from Welsh Mountain ewes infused with saline (control) or $1 \mu \mathrm{g} / \mathrm{h}$ human recombinant leptin (leptin) for $72 \mathrm{~h}$ in the late luteal phase of the oestrous cycle.

\begin{tabular}{|c|c|c|c|c|}
\hline Probe & Treatment & Number of positive follicles per ovary & Diameter of positive follicles $(\mathrm{mm})$ & $\begin{array}{c}\text { mRNA concentration } \\
\text { (arbitrary units of absorbance) }\end{array}$ \\
\hline \multirow[t]{2}{*}{ Aromatase } & Control & $1.2 \pm 0.5$ & $4.1 \pm 1.36$ & $0.07 \pm 0.02$ \\
\hline & Leptin & $1.0 \pm 0.0$ & $5.0 \pm 0.26$ & $0.10 \pm 0.00$ \\
\hline \multirow[t]{2}{*}{ IGF-IR } & Control & $10.7 \pm 0.8^{\mathrm{a}}$ & $1.8 \pm 0.20$ & $0.15 \pm 0.01$ \\
\hline & Leptin & $7.4 \pm 0.8^{\mathrm{b}}$ & $2.0 \pm 0.24$ & $0.14 \pm 0.02$ \\
\hline \multirow[t]{2}{*}{ IGFBP-2 } & Control & $10.0 \pm 0.8^{\mathrm{a}}$ & $1.5 \pm 0.15^{\mathrm{a}}$ & $0.30 \pm 0.01^{\mathrm{a}}$ \\
\hline & Leptin & $5.2 \pm 0.9^{b}$ & $2.2 \pm 0.31^{\mathrm{b}}$ & $0.39 \pm 0.02^{b}$ \\
\hline \multirow[t]{2}{*}{ IGFBP-4 } & Control & 2 & $2.3,2.1^{*}$ & $0.13,0.13^{*}$ \\
\hline & Leptin & - & - & - \\
\hline \multirow[t]{2}{*}{ IGFBP-5 } & Control & $5.2 \pm 1.60^{\mathrm{a}}$ & $1.9 \pm 0.14$ & $0.46 \pm 0.01^{\mathrm{a}}$ \\
\hline & Leptin & $1.2 \pm 0.300^{b}$ & $2.0 \pm 0.70$ & $0.25 \pm 0.05^{\mathrm{b}}$ \\
\hline \multirow[t]{2}{*}{$\mathrm{Ob}-\mathrm{R} b^{1}$} & Control & $0.25 \pm 0.25^{\mathrm{a}}$ & $1.57^{*}$ & $0.28^{*}$ \\
\hline & Leptin & $1.40 \pm 1.17^{b}$ & $2.77 \pm 0.59$ & $0.17 \pm 0.08$ \\
\hline \multirow[t]{2}{*}{ Leptin $^{1}$} & Control & $1.00 \pm 1.00$ & $3.41 \pm 0.83$ & $0.10 \pm 0.01$ \\
\hline & Leptin & $1.40 \pm 0.91$ & $2.70 \pm 0.63$ & $0.07 \pm 0.01$ \\
\hline
\end{tabular}

For each probe, within columns, values with different superscripts differ significantly $(P<0.05)$.

* Individual values.

${ }^{1}$ Not all follicles were assessed with these two probes.

endometrial glands of the placentome was confirmed (data not shown). Sections of placentome were used as positive controls for the analysis of ovarian tissues.

The expression of mRNAs for IGF-IR, IGFBP-2, -4 and -5 was detected (Fig. 1) in a variable proportion of the ovarian follicles examined. Of the follicles that were examined, IGF-IR mRNA was detected in 63 out of 93 $(6.7 \%)$ follicles from all nine ewes (Table 2). For the three binding proteins the corresponding figures are as follows: IGFBP-2 detected in 47 out of 93 follicles (50.3\%) from eight of nine ewes; IGFBP-4 detected in only two follicles from the control group; and IGFBP-5 detected in 18 out of 93 follicles (19.4\%) from seven of nine ewes (Table 2).

Leptin infusion reduced the number of IGF-IR-positive follicles $(P<0.05)$ without affecting their diameter or mRNA concentration (Table 3). The expression of IGF-IR mRNA was detected as previously reported in both the membrana granulosa and the thecal layers of the follicle (Perks et al. 1995, Muñoz-Gutiérrez et al. 2004).

The number of follicles with mRNA for IGFBP-2 was reduced by leptin infusion $(P<0.05$; Table 3$)$ but the maximum diameter of IGFBP-2-positive follicles $(P<0.05)$ and the concentration of mRNA $(P<0.05)$ were both increased significantly by leptin infusion (Table 3). As previously reported (Muñoz-Gutiérrez et al. 2004) the expression of IGFBP-2 mRNA was confined to the membrana granulosa of the follicle.

The mRNA for IGFBP-4 was detected in the theca cell layer in only 2 out of 93 follicles that were examined (Table 3); both of these were in the control group.

Leptin infusion reduced the number of IGFBP-5-positive follicles without affecting their mean follicular diameter but it increased the concentration of mRNA $(P<0.05$; Table 3). The expression of IGFBP-5 mRNA was detected in both the membrana granulosa and the thecal layers of the follicle. There were 18 follicles $(19.4 \%)>1 \mathrm{~mm}$ in diameter that were positive for IGFBP-5, and in all of these mRNA expression was confined to the membrana granulosa. Many follicles $<1 \mathrm{~mm}$ in diameter were also positive for IGFBP-5 and although these were not counted it was noted that when any of these small follicles expressed mRNA for IGFBP-5, expression was confined to the thecal cell layer.

\section{$\mathrm{Ob}-\mathrm{Rb}$ and leptin expression}

The presence of mRNA for Ob-Rb was confirmed in the ventromedial and arcuate nuclei of the ovine hypothalamus (Williams et al. 1999, Archer et al. 2002) and sections of ovine hypothalamus were used as a positive control for the analysis of ovarian tissues. Similarly, leptin mRNA expression previously detected by RT-PCR in ovine placenta (Buchbinder et al. 2001, Hoggard et al. 2001, Thomas et al. 2001) was confirmed here by in situ hybridization in sections of ovine placentome that were used as positive controls for the analysis of ovarian tissues.

Low but uniform expression of mRNA for Ob-Rb was detected in the granulosa cells of eight (9.4\%) follicles of a total of 85 that were examined (Fig. 2). The pattern of expression for leptin and $\mathrm{Ob}-\mathrm{Rb}$ were indistinguishable in individual follicles from control and treated animals. However, leptin infusion did increase the number of Ob-Rb mRNA-positive follicles ( $P=0.05$; Table 3 ) without affecting their mean diameter or the mRNA concentration (Table 3).

Leptin mRNA expression was detected in the theca and granulosa cells (Fig. 3) of 11 (42.3\%) follicles from a total of 26 follicles that were examined. Leptin infusion did not affect the number of follicles with mRNA for leptin, their 

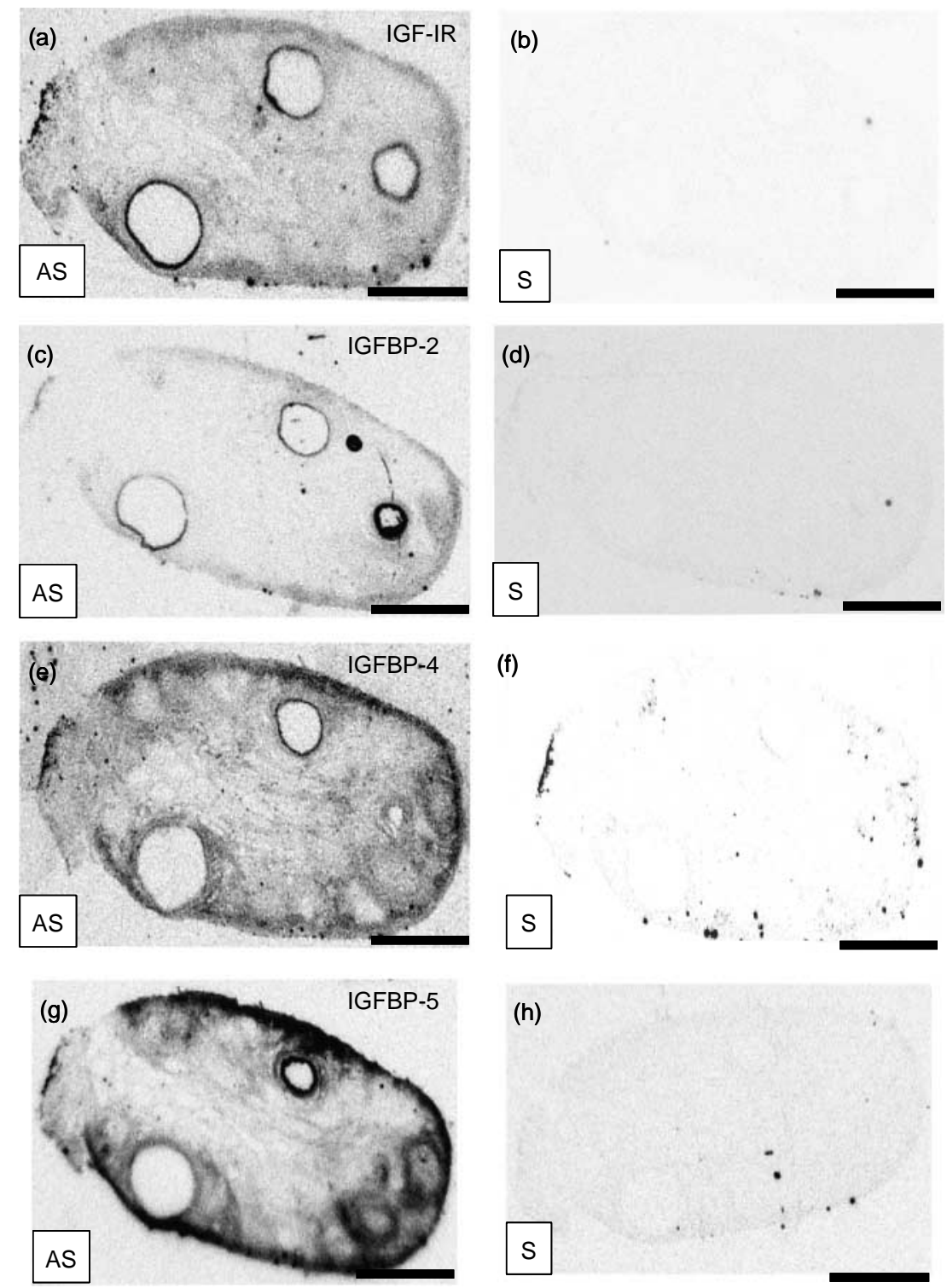

Figure 1 Autoradiographic localization of mRNA for IGF-IR (a and b), IGFBP-2 (c, d), IGFBP-4 (e and f) and IGFBP-5 (g and h) in follicular phase ovaries from Welsh Mountain ewes infused with saline (control) or $1 \mu \mathrm{g} / \mathrm{h}$ human recombinant leptin for $72 \mathrm{~h}$ in the late luteal phase of the oestrous cycle. Antisense (AS; a, c, e and g) and sense (S; b, d, f and h) probes are illustrated. Scale bars represent $2.5 \mathrm{~mm}$.

mean diameter or the level of expression of leptin mRNA (Table 3).

\section{Co-expression in aromatase-positive follicles}

Co-expression was determined by analysis of adjacent sections of the same follicle. Co-expression of mRNA for IGF-IR, IGFBP-2 or -5 with aromatase was detected in ten out of ten, six out of ten and one out of ten follicles respectively. There was no effect of treatment on these proportions for IGF-IR and IGFBP-5 but for IGFBP-2 the effect was significant (one out of five vs five out of five for control and leptin-infused ewes; $P=0.024$ ). Aromatase expression was not related to the presence of mRNA for IGF-IR or IGFBP-2 or -5 .
Co-expression of mRNA for Ob-Rb or leptin with aromatase was detected in three out of ten follicles for $\mathrm{Ob}-\mathrm{Rb}$ and in four out of six follicles for leptin. There was no effect of treatment on this pattern for leptin but for $\mathrm{Ob}-\mathrm{Rb}$ the effect approached significance (none out of five vs three out of five for control and leptin-infused; $P=0.083)$. Aromatase expression was not related to the presence of mRNA for leptin or Ob-Rb.

\section{Oestradiol, FSH, glucose and insulin}

During the leptin infusion, plasma oestradiol concentrations declined steadily in leptin-infused ewes (Fig. 4) and the concentration of oestradiol in leptin-infused ewes was significantly lower than controls at $48 \mathrm{~h}(P<0.01)$ 

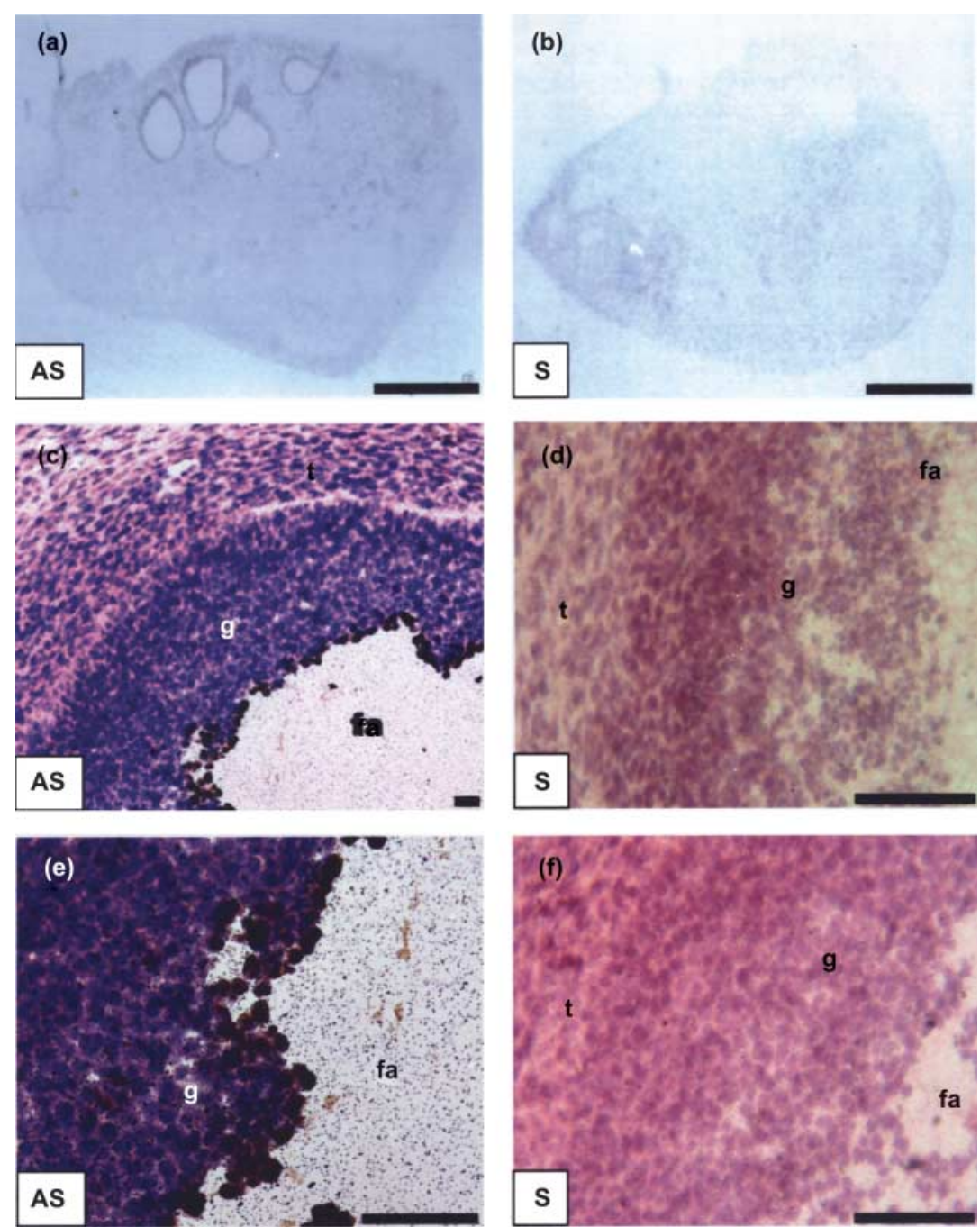

Figure 2 Autoradiographic localization of mRNA for the long signalling of leptin receptor (Ob-Rb) in follicular phase ovaries from Welsh Mountain ewes infused with saline (control) or $1 \mu \mathrm{g} / \mathrm{h}$ human recombinant leptin for $72 \mathrm{~h}$ in the late luteal phase of the oestrous cycle. Note the localization of $\mathrm{Ob}-\mathrm{Rb}$ in the inner layer of the membrana granulosa bordering the antrum and its absence in theca cells. Antisense (AS; a, c and e) and sense (S; b, $d$ and f) probes are illustrated. Code: fa: follicular antrum; g: granulosa cells; t: theca cells. Each scale bars represent (a and b) $2.5 \mathrm{~mm}$ and (c-f) $10 \mu \mathrm{m}$.

and $72 \mathrm{~h}(P<0.05)$. Following the end of the infusion and the induction of luteolysis with a PG injection, oestradiol concentrations increased significantly in both groups (Fig. 4) by $8 \mathrm{~h}$ and remained significantly $(P<0.05)$ elevated for the remainder of the experiment in both control $(19.9 \pm 2.30$ (S.E.M.) pmol/l) and leptin-infused ewes $(16.1 \pm 1.36 \mathrm{pmol} / \mathrm{l})$. However, oestradiol concentrations post-infusion were significantly lower in the leptin-infused ewes than control ewes $8 \mathrm{~h}(P<0.01), 16 \mathrm{~h}(P<0.05)$ and $32 \mathrm{~h}(P<0.05)$ after the end of the infusion (Fig. 4$)$.

The plasma concentration of FSH had increased significantly $(P<0.01)$ by $24 \mathrm{~h}$ after the start of infusion and it remained elevated for the duration of the infusion, decreasing to control levels by $24 \mathrm{~h}$ after the end of the leptin infusion (Fig. 4). The mean plasma concentration of
FSH was significantly increased both during $(1.36 \pm 0.05$ vs $1.95 \pm 0.09 \mathrm{ng} / \mathrm{ml} ; P<0.001)$ and after $(1.26 \pm 0.16$ vs $1.70 \pm 0.17 \mathrm{ng} / \mathrm{ml} ; P<0.003)$ the leptin infusion.

The mean plasma concentration of glucose was not affected by leptin infusion $(51.8 \pm 1.75$ and $52.3 \pm 4.15 \mathrm{mg} / \mathrm{dl}$ for control and leptin-infused groups respectively) and there was no significant effect of time, nor were there significant time by treatment interactions.

The mean plasma concentration of insulin was significantly increased by leptin infusion $(0.24 \pm 0.01$ vs $0.75 \pm 0.12 \mathrm{ng} / \mathrm{ml} ; P<0.001)$. The plasma concentration of insulin had increased significantly $(P<0.01)$ by $8 \mathrm{~h}$ after the start of infusion and it remained elevated for the duration of the infusion decreasing to control levels by $8 \mathrm{~h}$ after the end of the leptin infusion (Fig. 5). 

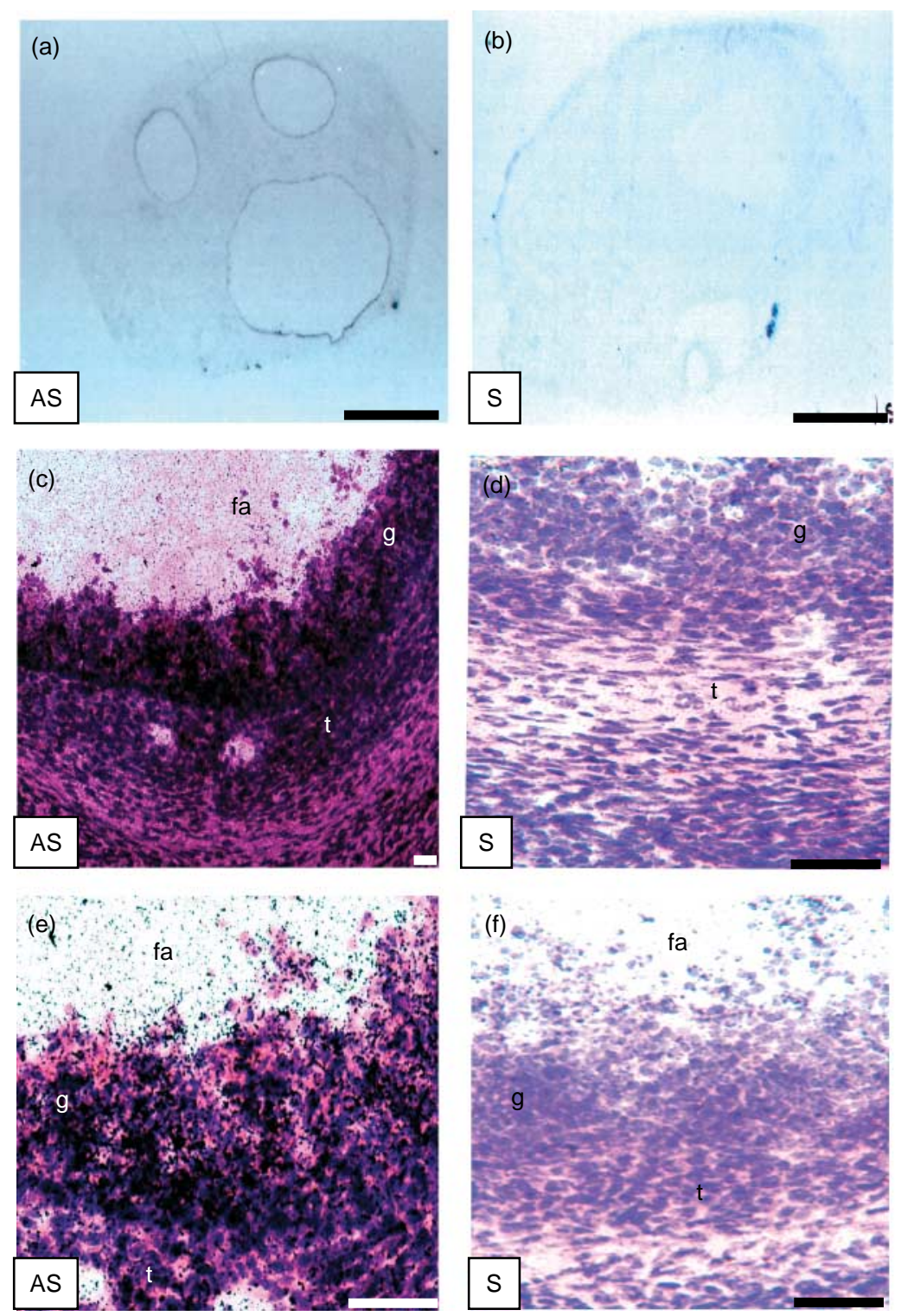

Figure 3 Antisense (AS; $a, c$ and e) and sense ( $;$; b, d and f) autoradiographic localization of mRNA for leptin in follicular phase ovaries from Welsh Mountain ewes infused with saline (control) or $1 \mu \mathrm{g} / \mathrm{h}$ human recombinant leptin for $72 \mathrm{~h}$ in the late luteal phase of the oestrous cycle. Code: fa: follicular antrum; g: granulosa cells; t: theca cells. Each scale bars represent (a and b) $2.5 \mathrm{~mm}$ and (c-f) $10 \mu \mathrm{m}$.

\section{Discussion}

An important finding from this experiment is the detection of mRNA for Ob-Rb in ovine granulosa cells (Fig. 2) from a proportion of the antral follicle population. The expression was weak but unequivocal, confirming that the granulosa cell is a physiological target for leptin. The presence of mRNA for leptin in granulosa and theca cells of antral follicles (Fig. 3) suggests that leptin is produced locally and that it may exert autocrine and/or paracrine effects on granulosa cell function.

The results of the present study and those of Kendall et al. (2004) show that human recombinant leptin is physiologically active in sheep at an infusion rate of
$1 \mu \mathrm{g} / \mathrm{h}$. This is a considerably lower dose that that used in other published studies (Spicer \& Francisco 1998, Greisen et al. 2000, Spicer et al. 2000) and suggests that in some of these earlier studies the dose of leptin used may not have been physiological. The infusion rate used in this experiment produced blood concentrations of leptin (Kendall et al. 2004) that fell within the $0.5-2 \mathrm{ng} / \mathrm{ml}$ reported physiological blood concentrations for leptin in sheep (Blache et al. 2000, Delavaud et al. 2000, Kauter et al. 2000, Kadokawa et al. 2003). A short-term infusion of leptin at a dose of $1 \mu \mathrm{g} / \mathrm{h}$ stimulated folliculogenesis by increasing the number of follicles $\geq 3.5 \mathrm{~mm}$ in diameter but with no effect on the number of follicles in the $\geq 1<3.5 \mathrm{~mm}$ class (Tables 2 and 3 ). Since most of the 


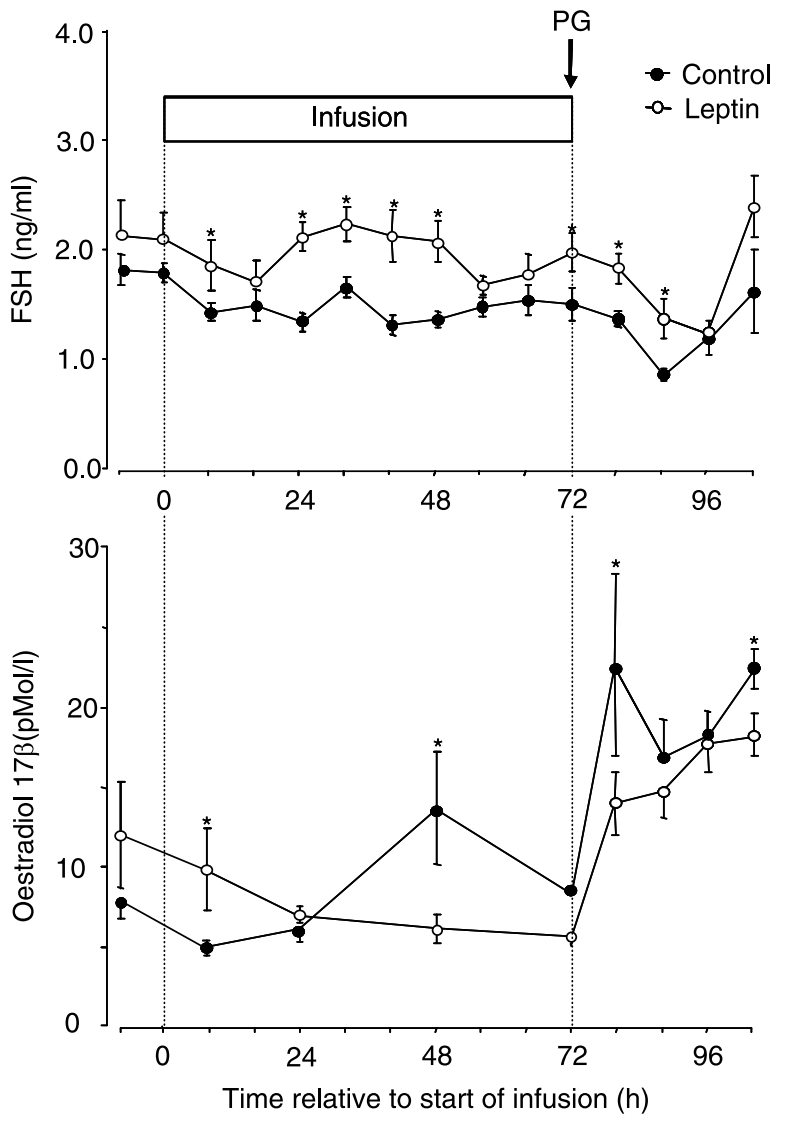

Figure 4 Mean \pm S.E.M. plasma concentration of oestradiol- $17 \beta$ and FSH in Welsh Mountain ewes infused with saline (control, $n=4$ ) or $1 \mu \mathrm{g} / \mathrm{h}$ human recombinant leptin (leptin, $n=5$ ) for $72 \mathrm{~h}$ in the late luteal phase of the oestrous cycle $(* P<0.05$ between treatment within time). Prostaglandin F2 $\alpha$ (PG, $125 \mu \mathrm{g}$ ) was injected at the end of the infusion period $(72 \mathrm{~h}$ ) and the ewes were killed $32 \mathrm{~h}$ later (104 $\mathrm{h}$ after the start of infusion).

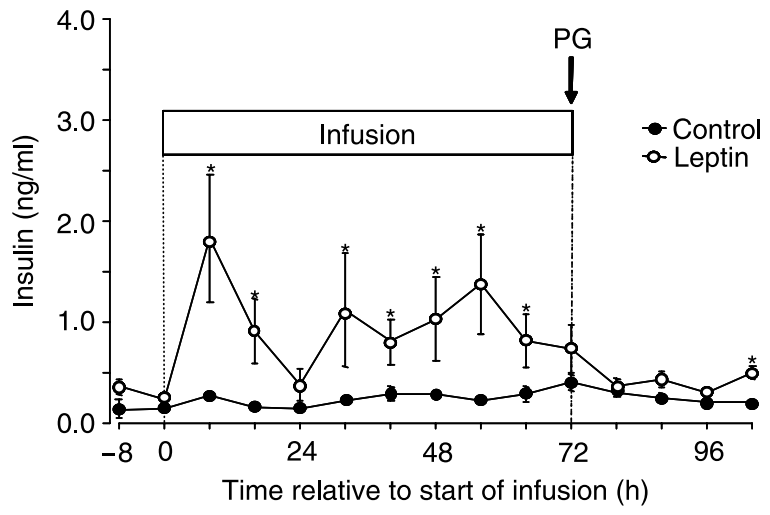

Figure 5 Mean \pm S.E.M. plasma concentration of insulin in Welsh Mountain ewes infused with saline (control, $n=4$ ) or $1 \mu \mathrm{g} / \mathrm{h}$ human recombinant leptin (leptin, $n=5$ ) for $72 \mathrm{~h}$ in the late luteal phase of the oestrous cycle ( $* P<0.05$ between treatment within time). Prostaglandin F2 $\alpha$ (PG, $125 \mu \mathrm{g}$ ) was injected at the end of the infusion period $(72 \mathrm{~h})$ and the ewes were killed $32 \mathrm{~h}$ later $(104 \mathrm{~h}$ after the start of infusion). follicles positive for leptin and Ob-Rb were $<3.5 \mathrm{~mm}$ (Tables 2 and 3) these results suggest that leptin is acting on these smaller recruited follicles, stimulating their growth and thus increasing the number of follicles $\geq 3.5 \mathrm{~mm}$. In ewes, the follicles that ovulate are those that avoid atresia and reach the final stage of development (Oldham et al. 1990, Scaramuzzi et al. 1993) and follicles $>3.5 \mathrm{~mm}$ are generally considered capable of ovulating (Scaramuzzi et al. 1993, Rhind \& McNeilly 1998). In the rat, physiological doses of leptin increased the number of ovulations 2 -fold, and accelerated follicular maturation by attenuating atresia and increasing the ratio of the antiapoptotic $\mathrm{BCl}_{2}-\mathrm{Bax}$ dimer (Almog et al. 2001). These findings lead us to suggest that in the ewe improved nutrition and higher body weight, which both elevate plasma leptin concentrations (Dyer et al. 1997, Blache et al. 2000, Delavaud et al. 2000, Kauter et al. 2000, Marie et al. 2001, Muñoz-Gutiérrez et al. 2002, Kosior-Korzecka \& Bobowiec 2003, Narro et al. 2003) may increase ovulation rate by a leptin-mediated mechanism.

In our work, the number of large potentially ovulatory follicles was doubled in leptin-infused ewes. However, the number of large follicles is not necessarily a reliable indicator of ovulation rate, because they must also be oestrogenic if they are to ovulate (Webb et al. 1989) and the number of follicles that were aromatase-positive was not increased by leptin infusion.

In the present study, the plasma concentration of oestradiol was decreased by leptin and further low oestradiol production was not associated with reduced aromatase mRNA expression. Early reports demonstrated that leptin could inhibit in vitro oestradiol production in cultured granulosa cells from the rat (Zachow \& Magoffin 1997, Zachow et al. 1999), cow (Spicer \& Francisco 1997) and in human granulosa lutein cells (Agarwal et al. 1999, Greisen et al. 2000, Ghizzoni et al. 2001) under a variety of conditions. Our findings provide further in vivo confirmation for these in vitro studies and suggest that leptin has a direct physiological action on the follicle. The finding also indicates that the suppressive effect of leptin on follicular oestradiol production is not caused by reduced aromatase mRNA expression and suggests that the negative modulation of oestradiol production is caused by some other aspect of aromatase function such as its translation, activation or activity per se (Zachow et al. 1999).

Much of the published evidence suggests that the ovarian actions of leptin involve an interaction with the ovarian IGF system. In human granulosa lutein cells, leptin directly attenuates IGF-I-stimulated oestradiol production (Huang et al. 2002). In bovine theca and granulosa cells cultured in vitro, insulin-induced progesterone, androstenedione and oestradiol production are all inhibited by leptin (Spicer \& Francisco 1997, 1998). The results of our experiment (Table 3) show that some components of the IGF system are directly altered by leptin and provide in vivo evidence that supports a role for leptin as a modulator of the ovarian IGF system. 
The numbers of follicles that were positive for IGF-IR or IGFBP-2 or -5 were all reduced by leptin (Table 3), and in particular those follicles between 1.3 and $2.5 \mathrm{~mm}$ in diameter. These are recruited follicles (McNatty et al. 1982, Scaramuzzi et al. 1993, Souza et al. 1998, Bartlewski et al. 1999) in a rapid growth phase (Scaramuzzi et al. 1993, Monget \& Martin 1997, Driancourt 2001). These findings suggest that leptin is most effective at modifying the IGF system of rapidly growing follicles around $2 \mathrm{~mm}$ in diameter.

In follicles that were $\geq 3.5 \mathrm{~mm}$ in diameter, the effects of leptin on the IGF system were predominantly on mRNA expression for IGFBP-2. Virtually all the follicles $\geq 3.5 \mathrm{~mm}$ in diameter were positive for IGF-IR mRNA, and leptin had no effect on the pattern of expression. However, leptin infusion significantly decreased the proportion of follicles $\geq 3.5 \mathrm{~mm}$ in diameter that were positive for mRNA for IGFBP-2 (Table 2). Only one follicle that was $\geq 3.5 \mathrm{~mm}$ in diameter had any detected IGFBP-5 mRNA expression.

No mRNA expression for IGFBP-4 was detected in any follicle from the leptin-infused group of ewes and only two IGFBP-4-positive follicles were detected in the control ewes. Nevertheless, IGFBP-4 is an essential component of follicular growth and development (Mazerbourg et al. 2001, Monget et al. 2002, Richards et al. 2002) and its presence in sheep follicles, especially atretic follicles, as both protein and message has been widely reported (Besnard et al. 1996, Perks \& Wathes 1996, Mazerbourg et al. 2001). The inhibition of IGFBP-4's biological activity by proteolytic cleavage (Mazerbourg et al. 2001, Wright et al. 2002) is a common feature of preovulatory follicles in human, ovine and bovine ovaries. The low incidence of IGFBP-4-positive follicles in this study suggests that mRNA expression for IGFBP-4 is also inhibited during the late follicular phase of the oestrous cycle.

The results of the present experiment show that leptin can modify IGFBP-2 and -5 mRNA expression and imply that leptin modulation of follicular function involves these two binding proteins as intermediaries. The binding proteins could have direct stimulatory effects on the follicle because IGFBP-2 and -5 can bind to components of the extracellular matrix (Robinson et al. 2000), which is involved in follicular remodelling. Our results are consistent with those of Monniaux et al. (2000), who reported decreased IGFBP-2 and -5 protein expression during terminal follicular growth. Our data suggest that IGFBP-2 is acting to attenuate follicular development (Table 3) because leptin induced both increased expression of IGFBP-2 and suppression of oestradiol production.

The infusion of leptin increased the number of follicles that expressed mRNA for Ob-Rb (Table 2). Ob-Rb mRNA expression was seen predominantly in follicles around $2.0 \mathrm{~mm}$ in diameter, follicles that had already been recruited and were rapidly growing. We suggest that endogenous leptin acts on recruited follicles to inhibit oestradiol secretion (Fig. 4) and enhance their survival by blocking IGFBP-2 and -5 expression (Table 3) to increase the number of large follicles (Table 2).

Leptin has also been implicated in other metabolic pathways including insulin (McClain 1998). Leptin increased insulin plasma concentrations without altering glucose concentrations, suggesting that in the ewe leptin acts as a trigger for insulin secretion independently of blood glucose concentrations. Leptin stimulates insulin secretion by a direct action on pancreatic insulinproducing $\beta$-cells (Ukropec et al. 2001). Our results agree with Zieba et al. (2003), who demonstrated that leptin has a dose-dependent bimodal influence on pancreatic $\beta$ cells, and low doses of leptin stimulated pancreatic $\beta$-cell responses while the high doses attenuated them. These findings and our own both suggest that care is required when interpreting the physiological consequences of leptin in experiments that use non-physiological doses of leptin (Henry et al. 1999, Morrison et al. 2001).

The lack of effect of leptin on blood glucose concentrations in the presence of elevated insulin concentrations suggests that leptin induced a mild degree of insulin resistance in our animals. This suggestion is consistent with leptin-attenuated insulin-stimulated functions such as lipogenesis, glycogen synthesis and amino acid uptake. However, in sheep, leptin signals body fat and nutrient stores rather than short-term changes in glucose utilization (Kauter et al. 2000). The effects of leptin on glucose utilization are indirect, at a neuronal level, and reduce whole body insulin sensitivity (Houseknecht \& Portocarrero 1998) leading to increased insulin concentrations without affecting blood glucose concentrations.

We conclude that in the ewe, a short-term $(72 \mathrm{~h})$ physiological infusion of leptin at $1 \mu \mathrm{g} / \mathrm{h}$ has a stimulatory effect on ovine follicular development and increases the number of large follicles ( $\geq 3.5 \mathrm{~mm}$ in diameter). However, leptin also inhibited follicular oestradiol production leading to an increase in blood concentrations of FSH. The action of leptin in follicles appears to be mediated by the IGF system because leptin reduced the number of follicles with mRNA for IGF-IR and IGFBP-2 and -5 without affecting the number with mRNA for aromatase. We suggest that these actions of leptin on the IGF system decrease bioavailability of IGF-I, resulting in decreased oestradiol production.

\section{Acknowledgements}

We wish to thank Dr James Goding (Melbourne, Australia) for the gift of the human recombinant leptin used in this experiment and Dr Amanda J Leigh for her valuable comments on the manuscript. Technical support provided by Ms Ros Foot is gratefully acknowledged. This research was supported by a grant from BBSRC. MM-G was supported by a studentship from CONACYT Mexico. The authors declare that there is no conflict of interest that would prejudice the impartiality of this scientific work. 


\section{References}

Agarwal SK, Vogel K, Weitsman SR \& Magoffin DA 1999 Leptin antagonizes the insulin-like growth factor-I augmentation of steroidogenesis in granulosa and theca cells of the human ovary. Journal of Clinical Endocrinology Metabolism 84 1072-1076.

Almog B, Gold R, Tajima K, Dantes A, Salim K, Rubinstein M, Barkan D, Homburgh R, Lessing JB, Nevo N, Gertler A \& Amsterdam A 2001 Leptin attenuates follicular apoptosis and accelerates the onset of puberty in immature rats. Molecular and Cellular Endocrinology 183 179-191.

Archer ZA, Rhind SM, Findlay PA, Kyle CE, Thomas L, Marie M \& Adam CL 2002 Contrasting effects of different levels of food intake and adiposity on LH secretion and hypothalamic gene expression in sheep. Journal of Endocrinology 175 383-393.

Armstrong DG, Gong JG \& Webb R 2003 Interactions between nutrition and ovarian activity in cattle: physiological, cellular and molecular mechanisms. Reproduction Supplement 61 403-414.

Bartlewski PM, Beard AP, Cook SJ, Chandolia RK, Honaramooz A \& Rawlings NC 1999 Ovarian antral follicular dynamics and their relationships with endocrine variables throughout the oestrous cycle in breeds of sheep differing prolificacy. Journal of Reproduction and Fertility 115 111-124.

Besnard N, Pisselet C, Zapf J, Hornebeck W, Monniaux D \& Monget P 1996 Proteolytic activity is involved in changes in intrafollicular insulin-like growth factor-binding protein levels during growth and atresia of ovine ovarian follicles. Endocrinology 137 1599-1607.

Blache D, Tellman RL, Chagas LM, Blackberry MA, Vercoe PE \& Martin GB 2000 Level of nutrition affects leptin concentrations in plasma and cerebral spinal fluid in sheep. Journal of Endocrinology 165 625-637.

Brannian JD, Zhao Y \& McElroy M 1999 Leptin inhibits gonadotrophin-stimulated granulosa cells progesterone production by antagonizing insulin action. Human Reproduction 14 1445-1448.

Buchbinder A, Lang U, Baker RS, Khoury JC, Merson J \& Clark KE 2001 Leptin in the ovine fetus correlates with fetal and placental size. American Journal of Obstetrics and Gynecology 185 786-791.

Campbell BK, Gordon BM \& Scaramuzzi RJ 1994 The effect of ovarian arterial infusion of transforming growth factor alpha on ovarian follicles populations and ovarian hormone secretion in ewes with an autotransplanted ovary. Journal of Endocrinology 143 $13-24$.

Carr JM, Grant PA, Francis GL, Owens JA, Wallace JC \& Walton PE 1994 Isolation and characterization of ovine IGFBP-4: protein purification and cDNA sequence. Journal of Molecular Endocrinology 13 219-236.

Cioffi JA, Van Blerkom J, Antczak M, Shafer A, Wittmer S \& Snodgrass HR 1997 The expression of leptin and its receptors in preovulatory human follicles. Molecular Human Reproduction 3 $467-472$.

Clarke IJ \& Henry BA 1999 Leptin and reproduction. Reviews in Reproduction 4 44-55.

Delavaud C, Boucquier F, Chilliard Y, Keisler DH, Gertler A \& Kann G 2000 Plasma leptin determination in ruminants: effect of nutritional status and body fatness on plasma leptin concentration assessed by a specific RIA in sheep. Journal of Endocrinology 165 519-526.

Delhanty PJ \& Han VK 1992 The characterization and expression of ovine insulin-like growth factor-binding protein-2. Journal of Molecular Endocrinology 9 31-38.

Driancourt MA 2001 Regulation of ovarian follicular dynamics in farm animals. Implications for manipulation of reproduction. Theriogenology 55 1211-1239.

Dyer CJ, Simmons JM, Matteri RL \& Keisler DH 1997 Leptin receptor mRNA is expressed in ewe anterior pituitary and adipose tissues and is differentially expressed in hypothalamic regions of well-fed and feed-restricted ewes. Domestic Animal Endocrinology 14 119-128.
Furbass R, Kalbe C \& Vanselow J 1997 Tissue-specific expression of the bovine aromatase-encoding gene uses multiple transcriptional start sites and alternative first exons. Endocrinology $\mathbf{1 3 8}$ 2813-2819.

Gadd TS, Osgerby JS \& Wathes DC 2000 Regulation and localization of insulin-like growth factor binding protein-5 gene expression in the uterus and placenta of the cyclic and early pregnant ewe. Biology of Reproduction 62 1415-1421.

Ghizzoni L, Barreca A, Masterakos G, Furlini M, Vottero A, Ferrari B, Chrousos GP \& Bernasconi S 2001 Leptin inhibits steroid biosynthesis by human granulosa-lutein cells. Hormone and Metabolic Research 33 323-328.

Greisen S, Ledet T, Møller N, Jørgensen JO, Christiansen SJ, Petersen K \& Ovesen P 2000 Effects of leptin on basal and FSH stimulated steroidogenesis in human granulosa luteal cells. Acta Obtetricia et Gynecologica Scandinavica 79 931-935.

Henry BA, Goding JW, Alexander WS, Tilbrook AJ, Canny BJ, Dunshea F, Rao A, Mansell A \& Clarke IJ 1999 Central administration of leptin to ovariectomised ewes inhibit food intake without affecting the secretion of hormones from the pituitary gland: evidence for a dissociation of effects on appetite and neuroendocrine function. Endocrinology $1401175-1182$.

Hoggard N, Haggarty P, Thomas L \& Lea RG 2001 Leptin expression in placental and fetal tissues: does leptin have a functional role? Biochemical Society Transactions 29 57-63.

Houseknecht KL \& Portocarrero CP 1998 Leptin and its receptors: regulators of whole-body energy homeostasis. Domestic Animal Endocrinology 15 457-475.

Houseknecht KL, Portocarrero CP, Lemenager R \& Spurlock ME 2000 Growth hormone regulates leptin gene expression in bovine adipose tissue: correlation with adipose IGF-1 expression. Journal of Endocrinology 164 51-57.

Huang H, Chen D, Zhu Y, Yang X, Jin M \& Jl M 2002 Study of the effects of leptin on cultured human luteinized granulosa cell function. Zhonghua Fu Chan Ke Za Zhi 37 152-154.

Kadokawa H, Briegel JR, Blackberry MA, Blache D, Martin GB \& Adams NR 2003 Relationships between plasma concentrations of leptin and other metabolic hormones in $\mathrm{GH}$-transgenic sheep infused with glucose. Domestic Animal Endocrinology 24 219-229.

Karlsson C, Lindell K, Svensson E, Bergh C, Lind P, Billing H, Carlsson LMS \& Carlsson B 1997 Expression of functional leptin receptors in the human ovary. Journal of Clinical Endocrinology and Metabolism 82 4144-4148.

Kauter M, Ball M, Kearney P, Tellman R \& McFarlane JR 2000 Adrenaline, insulin and glucagons do not have acute effects on plasma leptin in sheep: development and characterisation of an ovine leptin ELISA. Journal of Endocrinology 166 127-135.

Kendall NR, Guitierrez CG, Scaramuzzi RJ, Baird DT, Webb R \& Campbell BK 2004 Direct in vivo effects of leptin on ovarian steroidogenesis in sheep. Reproduction 128 757-765.

Kosior-Korzecka U \& Bobowiec R 2003 Changes in the level of endogenous leptin, FSH, 17beta-oestradiol and metabolites during lupin-induced increase in ovulation rate in ewes. Journal of Veterinary Medicine A50 343-349.

Löffler S, Aust G, Kohler U \& Spanel-Borowski K 2001 Evidence of leptin expression in normal and polycystic human ovaries. Molecular Human Reproduction 7 1143-1149.

Marie M, Findlay PA, Thomas L \& Adam CL 2001 Daily patterns of plasma leptin in sheep: effects of photoperiod and food intake. Journal of Endocrinology 170 277-286.

Mazerbourg S, Overgaard MT, Oxvig C, Christiasen M, Conover CA, Laurendenau I, Vidaud M, Tosser-Klopp G, Zapf J \& Monget P 2001 Pregnancy-associated plasma protein-A (PAPP-A) in ovine, bovine, porcine and equine ovarian follicles: involvement in IGF binding protein-4 proteolytic degradation and mRNA expression during follicular development. Endocrinology 142 5243-5253.

McClain DA 1998 Editorial: Further insights into leptin action. Endocrinology 139 3679-3680. 
McNatty KP, Gibb M, Dobson C, Ball K, Coster J, Heath D \& Thurley DC 1982 Preovulatory follicular development in sheep treated with PMSG and/or prostaglandin. Journal of Reproduction and Fertility 65 111-123.

Meikle A, Tasende C, Rodriguez M \& Garofalo EG 1997 Effects of oestradiol and progesterone on the reproductive tract and on uterine sex steroid receptors in female lambs. Theriogenology $\mathbf{4 8}$ $1105-1113$.

Mercer JG, Moar KM, Findlay PA, Hoggard N \& Adam CL 1998 Association of leptin receptor (OB-Rb), NPY and GLP-1 gene expression in the ovine and murine brainstem. Regulatory Peptides 75-76 271-278.

Monget P \& Martin GB 1997 Involvement on insulin-like growth factors in the interactions between nutrition and reproduction in female mammals. Human Reproduction 12 33-52.

Monget P, Monniaux D, Pisselet C \& Durand P 1993 Changes in insulin-like growth factor-I (IGF-I), IGF-II, and their binding proteins during growth and atresia of ovine ovarian follicles. Endocrinology 132 1438-1446.

Monget $P$, Fabre S, Mulsant $P$, Lecerf F, Elsen JM, Mazerbourg S, Pisselet C \& Monniaux D 2002 Regulation of ovarian folliculogenesis by IGF and BMP system in domestic animals. Domestic Animal Endocrinology 23 139-154.

Monniaux D, Monget P, Pisselet C, Fontaine J \& Elsen JM 2000 Consequences of the presence of the Booroola $\mathrm{F}$ gene on intraovarian insulin-like growth factor system and terminal follicular maturation in Merinos d'Arles ewes. Biology of Reproduction 63 1205-1213.

Morrison CD, Daniel JA, Holmberg BJ, Djiane J, Raver N, Gertler A \& Keisler DH 2001 Central infusion of leptin into well-fed and undernourished ewe lambs: effects on feed intake and serum concentrations of growth hormone and luteinizing hormone. Journal of Endocrinology 168 317-324.

Moser DR, Lowe WL Jr, Dake BL, Booth BA, Boes M, Clemmons DR \& Bar RS 1992 Endothelial cells express insulin-like growth factorbinding proteins 2 to 6. Molecular Endocrinology 6 1804-1814.

Muñoz-Gutiérrez M, Blache D, Martin GB \& Scaramuzzi RJ 2002 Folliculogenesis and ovarian expression of mRNA encoding aromatase in anoestrous sheep after five days of glucose or glucosamine infusion of supplementary lupin feeding. Reproduction 124 $721-731$.

Muñoz-Gutiérrez M, Blache D, Martin GB \& Scaramuzzi RJ 2004 Ovarian follicular expression of mRNA encoding the type I IGF receptor and IGF-binding protein-2 in sheep following five days of nutritional supplementation with glucose, glucosamine or lupins. Reproduction 128 747-756.

Narro LA, Thomas MG, Silver GA, Rozeboom KJ \& Keisler DH 2003 Body composition, leptin, and the leptin receptor and their relationship to the growth hormone $(\mathrm{GH})$ axis in growing wethers treated with zeranol. Domestic Animal Endocrinology 24 $243-255$.

Oldham CM, Lindsay DR \& Martin GB 1990 Effects of seasonal variation in live weight on the breeding activity in Merino ewes. In Reproductive Physiology of Merino sheep. Concepts and Consequences, pp 41-58. Eds CM Oldham, GB Martin, IW Purvis, Perth, Western Australia: School of Agriculture (Animal Science), University of Western Australia.

Perks CM \& Wathes DC 1996 Expression of mRNAs for insulin-like growth factor binding proteins-2, -3 and -4 in the ovine ovary throughout the oestrus cycle. Journal of Endocrinology 151 241-249.

Perks CM, Denning-Kendall PA, Gilmour RS \& Wathes DC 1995 Localization of messenger ribonucleic acids for insulin-like growth factor I (IGF-I), IGF-II and the type 1 IGF receptor in the ovine ovary throughout the estrus cycle. Endocrinology 136 5266-5273.

Reynolds TS, Stevenson KR \& Wathes DC 1997 Pregnancy-specific alterations in the expression of the insulin-like growth factor system during early placental development in the ewe. Endocrinology 138 886-897.
Rhind SM \& McNeilly AS 1998 Effects of level of food intake on ovarian follicle number, size and steroidogenic capacity in the ewe. Animal Reproduction Science 52 131-138.

Richards JS, Russell DL, Ochsner S, Hsieh M, Doyle KH, Faleder AE, Lo YK \& Sharma SC 2002 Novel signalling pathways that control ovarian follicular development, ovulation and luteinization. Recent Progress in Hormone Research 57 195-220.

Robinson RS, Mann GE, Gadd TS, Lamming GE \& Wathes DC 2000 The expression of the IGF system in the bovine uterus throughout the oestrous cycle and early pregnancy. Journal of Endocrinology $165231-243$.

Ruiz-Cortés ZT, Men T, Palin MF, Downey BR, Lacroix DA \& Murphy BD 2000 Porcine leptin receptor: molecular structure and expression in the ovary. Molecular Reproduction and Development 56 465-474.

SAS 1995 In System for Windows Release 6.12,Cary, NC: SAS Institute.

Scaramuzzi RJ, Adams NR, Baird DT, Campbell BK, Downing JA, Findlay JK, Henderson KM, Martin GB, McNatty KP, McNeilly AS \& Tsonis CG 1993 A model for follicles selection and the determination of ovulation rate in the ewe. Reproduction, Fertility, and Development 5 459-478.

Simmons JM, Dyer CJ \& Keisler DH 1997 In Direct submission of Ovis aries leptin mRNA. Genbank accession number U84247, Columbia, MO USA: Animal Science, University of Missouri.

Smith JF \& Stewart RD 1990 The effects of nutrition on the ovulation rate of ewes. In Reproductive Physiology of Merino Sheep - Concepts and Consequences, pp 85-101. CM Oldham, GB Martin, IW Purvis,, Eds.; Perth, Western Australia: School of Agriculture (Animal Science), University of Western Australia.

Souza CJ, Campbell BK \& Baird DT 1997 Follicular dynamics and ovarian steroid secretion in sheep during the follicular and early luteal phases of the oestrous cycle. Biology of Reproduction $\mathbf{5 6}$ 483-488.

Souza CJ, Campbell BK \& Baird DT 1998 Follicular waves and concentration of steroids and inhibin $\mathrm{A}$ in ovarian venous blood during the luteal phase of the oestrous cycle in ewes with an ovarian transplant. Journal of Endocrinology 56 563-572.

Spicer LJ 2001 Leptin: a possible metabolic signal affecting reproduction. Domestic Animal Endocrinology 21 251-270.

Spicer LJ \& Francisco CC 1997 The adipose obese gene product, leptin: evidence of a direct inhibitory role in ovarian function. Endocrinology $1383374-3379$.

Spicer LJ \& Francisco CC 1998 Adipose obese gene product, leptin, inhibits bovine ovarian thecal cell steroidogenesis. Biology of Reproduction 58 207-212.

Spicer LJ, Chamberlain CS \& Francisco CC 2000 Ovarian action of leptin: effects on insulin-like growth factor-I-stimulated action of granulosa and thecal cells. Endocrine 12 53-59.

Stoeltzing O, Liu W, Reinmuth N, Fan F, Parikh AA, Bucana CD, Douglas B, Evans DB, Semenza GL \& Ellis LM 2003 Regulation of hypoxia-inducible factor-1alpha, vascular endothelial growth factor, and angiogenesis by an insulin-like growth factor-l receptor autocrine loop in human pancreatic Cancer. American Journal of Pathology $1631001-1011$.

Thomas L, Wallace JM, Aitken RP, Mercer JG, Trayhurn P \& Hoggard N 2001 Circulating leptin during ovine pregnancy in relation to maternal nutrition, body composition and pregnancy outcome. Journal of Endocrinology 169 465-476.

Tsai EM, Yang CH, Chen SC, Liu YH, Chen HS, Hsu SC \& Lee JN 2002 Leptin affects pregnancy outcome of in vitro fertilization and steroidogenesis of human granulosa cells. Journal of Assisted Reproductive Genetics 19 169-176.

Ukropec J, Šeböková E \& Klimes I 2001 Nutrient sensing, leptin and insulin action. Archives of Physiology and Biochemistry 109 $38-51$. 
Viñoles, GC 2003 Effect of nutrition on follicle development and ovulation rate in the ewe PhD Thesis. Swedish University of Agricultural Sciences.

Wang HS \& Chard T 1999 IGFs and IGF-binding proteins in the regulation of human ovarian and endometrial function. Journal of Endocrinology 161 1-13.

Webb R, Gauld IR \& Driancourt MA 1989 Morphological and functional characteristics of large antral follicles in three breeds of sheep with different ovulation rates. Journal of Reproduction and Fertility 87 243-255.

Williams LM, Adam CL, Mercer JG, Moar KM, Slater D, Hunter L, Findlay PA \& Hoggard N 1999 Leptin receptor and neuropeptide $Y$ gene expression in the sheep brain. Journal of Neuroendocrinology 11 165-169.

Williams SA, Blache D, Martin GB \& Scaramuzzi RJ 2001 The effect of oral administration of a glucogenic mixture on ovulation rate and characterisation of GLUT1 and GLUT4 in sheep ovarian follicles. Journal of Reproduction and Fertility 122 947-956.

Wright RJ, Holly JMP, Galea R, Brincat M \& Mason HD 2002 Insulin-like growth factor (IGF)-independent effects of IGF binding protein-4 on human granulosa cell steroidogenesis. Biology of Reproduction 67 776-781.

Zachow RJ \& Magoffin DA 1997 Direct intraovarian effects of leptin: Impairment of the synergistic action of insulin-like growth factor-I on follicle-stimulating hormone-dependent estradiol-17beta production by rat ovarian granulosa cells. Endocrinology 138 $847-850$.

Zachow RJ, Weitsman SR \& Magoffin DA 1999 Leptin impairs the synergistic stimulation by transforming growth factor- $\beta$ of follicle stimulating hormone-dependent aromatase activity and messenger ribonucleic acid expression in rat ovarian granulosa cells. Biology of Reproduction 61 1104-1109.

Zamorano PL, Mahesh VB, De Sevilla LM, Chorich LP, Bhat GK \& Brann DW 1997 Expression and localization of the leptin receptor in endocrine and neuroendocrine tissues of the rat. Neuroendocrinology $65223-228$.

Zhang Y, Proenca R, Maffei M, Barone M, Leopold L \& Friedman JM 1994 Positional cloning of the mouse obese gene and its human homologue. Nature 372 425-432.

Zieba DA, Amstalden M, Maciel AN, Keisler DH, Raver N, Gertler A \& Williams GL 2003 Divergent effects of leptin on luteinizing hormone and insulin secretion are dose dependent. Experimental Biology and Medicine 228 325-330.

Received 22 July 2005

First decision 09 September 2005

Accepted 03 October 2009 